\title{
New Law-Making and Regulatory Welfare Trade-offs
}

\author{
-The European Union and Scandinavia Cases
}

\section{Noralv Veggeland}

Lillehammer University College, Lillehammer, Norway.

Email: noralv.veggeland@hil.no

Received March $18^{\text {th }}, 2011$; revised April 22 ${ }^{\text {nd }}, 2011$; accepted May $16^{\text {th }}, 2011$.

\begin{abstract}
The contemporary regulatory state has developed as a result of both new legislation and political struggles that accompanied an increasingly globalized world and the economic crisis in the 1970-1980s. The answer to this development was the reforms collectively known as New Public Management (NPM) which promoted the privatization and marketization of the public sector, and thereby the creation of the new regulatory state. The regulatory-state formation in Europe was affected extensively by the formation of the European Union and its administrative traditions and welfare-state models. Path-dependent developments influenced the achievements which have been described as innovative, that is, regulatory innovation. Socio-economic goals are linked to three distinct policy choices, which have been characterized by trade-offs. The trade-offs occur because it is difficult to pursue successfully all three goals simultaneously. In Scandinavia the trade-off and new law-making achieved as a regulatory innovation the much-lauded mechanism of "flexicurity", that is, the combination by law of the flexible market with social security.
\end{abstract}

Keywords: Regulatory State, Welfare State, Innovation, Trade-offs

\section{The Emergence of the Regulatory State ${ }^{1}$}

The development of Western welfare-states in the 1950s and 1960s until the mid-1970s took place under highly favorable circumstances, aided by continuous growth in the economies, and governments were able to manage national budgetary control [3]. Political economic analyses, therefore, characteristically emphasized a national, state-centered law perspective bound both to the technoeconomic paradigm rooted in Keynesian state intervention and principles of effective demand and to the socio-institutional paradigm of the Weberian bureaucracy [4].

However, in the wake of the stagflation crisis of the 1970s, there was pressure to modernize regulatory laws and to reduce government outlays through new structuring [5], and the European Union (EU) initiated its implementation. However, there has been the counterpressure of demographic changes, such as the growing rate of elderly people; that has led to such fiscal changes as the rising cost of health and elderly care, the liberali-

${ }^{1}$ The topic of the regulatory state is more broadly dealt with in Veggeland 2009, $2010[1,2]$. zation of national and international markets, and the changing nature of the labor market [6]. The questions have thus been how these countries acquire fiscal ability vis-à-vis the challenges presented by welfare and workfare without overloading public budgets and creating destructive inflation, and how can they harness the flexibility of the market while maintain their systems of social security.

Scandinavian political attitudes and legal approaches changed when the fiscal ability were threatened in the late 1970s to the 1980s with the onset of a severe worldwide economic recession. Suddenly, increasing unemployment rates, overloaded public budgets and the globalization of markets became pressing issues, which also challenged the European welfare-state models, including the Scandinavian one as well [1]. As we shall see, the situation in the Scandinavian country of Norway was exceptional because of a source of growing income from oil and gas, and this provided a bulwark against the development of high unemployment. Nevertheless, the stagflation crisis of the 1970s was felt in Norway as well, and the crisis turned out to be fertile ground for new thinking and the transformation in the organizations of 
economic production and the institutional functions of the state [7].

Market solutions and related new laws, including the downscaling of state financial involvement, arose and were legitimized by the EU and the neo-liberal ideology of the Anglo-Saxon New Public Management goals [8]. Paradoxically, this approach also created the conditions for the emergence of the regulatory state [1]. As Giandomenico Majone perceptively notes in his article, "The Emergence of the Regulatory State in Europe":

Privatization and deregulation have created the conditions for the rise of the regulatory state to replace the dirigiste state of the past ... reliance on regulation -rather than public ownership, planning or centralized administration characterizes the methods of the regulatory state [9].

One important factor for the privatization and deregulatory measures, the arrival of the regulatory state, was that politicians, the media and economists began to pay attention to the actual and potentially increasing welfare role of the market, driven by both public and private actors and agencies. This new focus was often linked to sharp criticism of the allegedly inefficient public bureaucracy and monopolies. The criticism of the costly welfare-state emanated not from the heavily burdened Organization for Economic Cooperation and Development (OECD) welfare-states of the Continental and Nordic welfare traditions [10], but rather from the "less advanced" or "less embracing" Western liberal welfarestates such as the UK and the USA. The OECD legitimized the criticism and skepticism through well received reports on the welfare state in crisis. The reports strongly promoted the strategy of deregulation, outsourcing instead of in-house provision of welfare services, marketdriven solutions in the public sector, and contracting as a new regulatory tool [11]. The modernizing of government in this way and the enactment of the reforms along the Anglo-Saxon path and NPM principles were the final recommendation of the OECD. New laws and innovative re-regulating efforts involving the public sector were now needed. Contextually, and to different extent, in the OECD area private law came to replace public law.

Further, the related neo-liberal ideology stressed the responsibility of individuals for themselves, the freedom to choose services, security through personal and/or employer health and social insurance, and so on. From the 1980s on, the international winds of ideological criticism and warnings against universal public welfare and social-security measures reached Scandinavia along with the regulatory-state approach [2]. The OECD neo-liberalism-biased strategy and recommendations still linger on in the documents coming from the organization [12].

The views of neo-liberalism, which were picked up and have been partly followed with very little deviation by the leading Scandinavian right-wing political parties since the 1980s, influenced the social democratic parties. A key word here is the belief in commercialization in order to increase efficiency in the public sector and in the welfare service sector [13]. Constituting an ideological front here are both the presentation of individually differentiated needs and rights with the liberating message of freedom to go "shopping" for services of your own and a message of inclusion by giving everyone the opportunity to be included in this system of freedom. The ideology of neo-liberalism has generated its own language that has promoted the biased attribution of good governance views and values to the market and bad governance views to the state. Ideologically, the principle of a necessary dominant regulatory state was left unmentioned. This list of ideologically blended words, which has been inspired by many scholarly sources and is dominant in OECD reports of recommendations on modernization issues, tries to clarify the contrasting views in a context of supremacy and inferior absolutism:

\begin{tabular}{ll}
\multicolumn{2}{c}{ Neo-liberal } \\
Market qualities & State qualities \\
Freedom & Enforcement \\
Individualism & Collectivism \\
Diversification & Uniformity \\
Open effective economy & Closed ineffective \\
& economy \\
Modernism & Entrapment in the past \\
Deregulation & Too much public law \\
Cost efficiency & Cost inefficiency \\
Elasticity & Deficit of flexibility \\
Mobility & Immobility \\
Progress & Lack of progress \\
Innovation & Standstill
\end{tabular}

The neo-liberal views are both partly right and partly wrong, but are somewhat realized in the Nordic countries in a transformed mode [14]. Throughout the last two decades, a new Nordic welfare and social order has risen to some degree. However, regulatory innovations in the field are blended with administrative traditions, and should be understood and interpreted as path-dependent innovations arising from the historical Scandinavian welfare-state model. We shall now compare the actual and basic transformations and trade-offs that challenge the welfare-state, and especially the universal welfarestate of the contemporary Nordic countries.

\section{Regulatory Welfare State Models in the EU}

The regulatory approaches of the European Union (EU), which is characterized by a regulatory state governing 
almost exclusively by laws and regulations, have heavily influenced the welfare-state performance of its member states and subsidiaries like Norway. From the launching of the European integration process and the adoption of the Treaty of Rome in the 1950s, and with the inner six Continental states, Germany, France, Italy and the three Benelux countries, as founder states, the Continental model naturally was dominant, and this administrative tradition created a path-dependence of state- focused con-federalism and interventionism as a reflection of the Keynesian state [15]. From the Continental tradition came the inspiration to introduce the policy to embrace into the governing mode of the EU the European social partners, the European umbrella trade union (ETUC) and the private and public employers' interest organizations, UNICE (now Businesseurope) and CEEP, respectively, to the negotiation table [16]. The goal was to tame and correct the integration process by putting regulatory social concerns on the agenda. A sort of a Continental corporatist style was the result. The Maastricht Treaty from 1992 introduced the "Social dimension" of the Community, with the expressed goal of creating arenas for deliberative talks, and thereby to reach consensus instead of conflict on social and labor-market issues. The Anglo-Saxon state, the UK, was exempted from the EU social dimension, and in 2008 the UK still remains outside this facet of EU policy.

The dominance of the Continental tradition lasted until the end of the 1980s [17]. The adoption of the Single European Act in 1987 and the introduction of the Single European Market process one year later marked a fundamental contextual change [18,19]. The strategies of minimizing the state and marketizing the public sector, both of Anglo-Saxon origin, became dominant policies [20]. Further, the member states decided to deregulate —and re-regulate by law - to create a territorially wider, borderless, single European market. The new regulatory state order of the EU had taken over. Governance replaced the governing mode of the Union. We might say that this caused the transformation of the social -institutional paradigm, much in accordance with the Anglo-Saxon social model and market-orientated administrative tradition, and expanded the need for innovative re-regulation in this multilevel governance (MLG) system.

How did such a transformation occur? When the United Kingdom had joined the European Community (EC) in 1972 as a major member state, the global recessions, inflation, unemployment and stagflation had reached all the member states' shores. The crises biased and pressed forward change, or at least modification, of

${ }^{2}$ Eastern European member states. the techno-economic and socio-institutional paradigms. The Anglo-Saxon model and the tradition of organizing governance became dominant and turned the Community's method away from state-focused con-federalism and interventionism and toward the direction of the regulatory-state paradigm based on market-centered policies, modes of New Public Management and supply-side economics. The concept of the social dimension and the involvement of social partners in negotiations, along with sensitive legal issues like work conditions and social and labor-market reforms, were temporary taken off the agenda [21].

During the 1990s, both the failure of the EU to compete in the global economy and the democratic and legitimacy deficits became central issues, threatening the core identity of the Union [22]. And when the Soviet Union collapsed, the political situation in Europe changed radically. The poor Eastern Europe states wanted membership status in the "rich men's club", and the Amsterdam Treaty of 1997 the opened the door to them [23]. Ten new states joined the Union in 2004, and two more in 2007, bringing with them heavy social and economic burdens that were expected and immediately felt. Reforms were necessary, and they were formulated, agreed on and implemented as socio-institutional changes. In our context of studying law-making for an alternative social model, the Lisbon Process, launched in 2000, was to be a crossroad [24]. The Lisbon Process targeted the ambitious goal of making the EU the most competitive region globally.

Hence, there were at least at two important events during the spring of 2006. European political and administrative leaders discussed modes of competitiveness and robust governance in relation to such models. Their explicit focal points were on the Nordic welfare-state model and its regulatory approach to social security and on whether such a successful model that offered low socio-economic risk and vulnerability could be applied to other member states, especially those in distress ${ }^{2}$ [25]. This idea motivated scholars to revisit the Nordic state-focused social model and participatory administrative tradition in a comparative perspective in order to find out the essential characteristics of the paths of development coming from this model and to determine why this dominantly public law-based welfare state model is considered successful "in the global age" [26-28].

As mentioned, the EU search for an innovative regulatory social model began when the European Council held its meeting 23-24 March 2000 in Lisbon and agreed to set out a new ten-year strategic goal for the European Union. The goal was to make the Union the most competitive and dynamic knowledge-based economy in the world and capable of sustainable economic growth with 
more and better jobs and greater social cohesion. The Lisbon Process was launched. But right from the start critical voices made themselves heard, like "Lisbon's single size does not fit all” [29], meaning that the Lisbon Process from the beginning was far too fixated on economic conditions for competitiveness and taming externalities at the expense of considerations of social security and welfare.

In short, the Nordic model seems to offer more than a "single-size" method in the pursuit of competitiveness [30]. The model seems to offer everything that European decision-makers are looking for: highly competitive economies in conjunction with less social inequalities and the institutionalized taming of risks and innovative regulations for job protection [27,31]. In the 2000s, this rather expensive welfare-state model appears to represent a multi-dimensional method that has the potential to generate a successful road for the development of the future $\mathrm{EU}$ and for (some of) its member states.

Of course, all these things are extremely complicated. We need European-wide multi-disciplinary comparative research to enhance the knowledge of what happens when EU laws and social models travel across borders.

\section{Welfare-State Models and Regulatory Innovation}

As elaborated above, we may view innovation in the public sector not as accidental changes but as contextual legal changes [32]. In the European context, it means that path-dependence, owing to different territorial social models, strongly influences such changes [26]. Another closely related issue arises regarding innovation. New ways of making such changes, and transcending them, also occur when European social models and their basic law pillars interact across borders and trigger interpretations of new ideas that bias policy and institutional change. Interpretation theory makes explicit that there are at least two basic perspectives involved [33]: the interpretation may be either contextual or out of context. In the former case, innovation is linked to already existing social models and traditions, and path-dependence thus determines the norms, principles and values [34]. In the latter case, there is the simple copying and imitating of first- or second-order changes without taking account of domestic values, management ethics and steering traditions.

In general, regulatory innovation ${ }^{3}$, i.e. new law- making, includes strategies for improving the management of risk and the pursuit of state legitimacy in the "risk society" [37]. Innovations in the way risk is moderated include threats to welfare, social security, labor market,

\footnotetext{
${ }^{3}$ Regulatory innovation is a dynamic part of the "regulatory state", see G
} Majone’s 1996, 1997 [35,36] elaboration about the latter term. social and human capital, gender discrimination or otherwise, environment, economy, national security, and so on [38]. Re-regulation, a term for new law- making aiming for the reduction of risk and taming purposes, is a term often used to express regulatory innovation, for example, providing social capital through market correction or the partnership approach [39].

Some researchers have pointed out that the welfare-state does not have its basis on "politics and regulation by law against the markets", as is commonly assumed in the neo-liberal Anglo-Saxon tradition, but rather on the social-democratic mixed-economy approach, that is, "politics and regulation by law with markets" [40]. We may add to this the postulation of "politics and regulation by law by the market" if we take into consideration how the principles of New Public Management and market-type mechanisms have penetrated the traditional Scandinavian welfare-state model and administrative tradition $[11,20]$ and constituted the current Nordic welfare and social model [26]. This change has innovatively formed and adapted a regulatory approach to a new stage of welfare-state performance. The three postulations seem reasonable, but we should qualify them with an answer to this question: which law-making and regulatory changes to the welfare state provide grea- ter output to its citizens more than others?

Although it is popular to point out that the market, including global markets, interferes with the welfare-state and vice versa, it is obvious that this interference occurs along different paths, depending on the actual social regulatory model of the states [41]. We have at least three general regulatory welfare-state models in Europe, which link correspondingly to the three administrative and political traditions [34]. Let us elaborate these somewhat further.

- The Continental welfare-state regulatory model, which is dominated by strong trade unions, is said to be of a corporatist type with a heavy regulated labor market. As discussed earlier, high job security and protection through industrial relations play a key role [26]. For this and other reasons, the corporatist welfare-states are, in many ways, based on politics and regulation by law against markets more than other European states. Administrative rigidity and a slow process of renewing social apparatus hamper the corporatist Continental welfare-state model. These features are not accidental but due to traditions and developments of institutional path-dependence [34].

- The Anglo-Saxon welfare-state regulatory model, which is dominated by the adoption of marketcentered policies, is said to be of a liberal type. The liberal welfare-states use market-type-mechanisms and independent agencies to provide welfare services. 
The labor market is sparsely regulated and has low job security and protection [27]. This welfare-state model more than others qualifies for the notion of politics and regulation by law by markets. With regard to innovation of social apparatus, the model is restricted by ideological resistance to changes which concern the basic values and principles of neoliberalism. Again, this occurs not accidentally but as a result of biases historically rooted in the liberal model, and we may best view it as an institutional pathdependent development.

- The Scandinavian/Nordic universal welfare-state regulatory model, which is dominated by statecentered policies and high welfare expenses, is of the universal type. The universal welfare-states offer universal social security and job-protection arrangements. Further, it is a governmental responsibility to prioritize such labor-market tasks as life-long learning and the development of skills. From another point of view the Nordic post-war labor market has become rather liberalized and the marketized, such as outsourcing which is often put to use for the provision of welfare services [12,26]. This makes the universal welfare-state model qualified for the notion of politics and regulation by law with market ${ }^{4}$ in the framework of the regulatory state. The public sector has selectively learned lessons especially from the Anglo-Saxon model, and in some parts of society the third-level of changes is reached, that is, innovative changes. This achievement concerns the concept of social capital, which has been renewed in the contemporary Nordic model. One example is how welfare politics has become connected to labor-market politics in an innovative way. The outcome has been the great law-based social regulatory innovation of "flexicurity", namely, the interactive co-play between universal social security regulated by law, and active labor-market policies, which brings flexibility to the labor market and therewith competitive advantages in the global age [27]. As with the other models, the contemporary universal Nordic model of the welfare state has also taken its form owing to its historical welfare-state roots and institutional path-dependence [42].

One main reason why the Nordic regulatory model has been receiving renewed EU attention under the auspices of the Lisbon Process since 2000 is the belief in the social capital of flexicurity and other universal welfarestate arrangements of the model [43]. In a time when

\footnotetext{
${ }^{4}$ Torben Iversen [40] discusses the notion of politics with markets, but explicitly does not link it to the Scandinavian welfare-state. It is probable that he also includes the Anglo-Saxon model or perhaps makes it a general notion. If this is so, I disagree.
}

states and regions are more than ever competing globally and are intensively engaged in political and economical measures to maintain a high employment rate while trying to keep inflation and public expenses low, it is understandable that they are looking for innovative solutions $[27,40]$. Records of public budgets confirm over the years, however, that the Nordic welfare and social-security costs consequently represent a high burden on the public budget. Why, then, is this regulatory model so attractive? The answer may be very simple: Social capital in the Nordic welfare-state regulatory model creates a high level of labor productivity. The labor productivity is generated through high degree of national employment, which means more than just "full employment” in the Keynesian sense. It means work, training or education for everybody irrespective of social groups, gender, ages and individual differences. The pay-off of this is ability to afford expensive social security, which in turn results in the taming of social inequality that facilitates the renewal of the social capital of flexicurity in an ascending innovative circle.

The empirically based thesis is that universal job protection and social security shape the incentives workers have both for investing in particular market-attractive skills and life-long learning and for changing work and work-places without personal risk. Labor market flexibility is the innovative outcome of the Nordic active labor-market policies: education, lifelong learning, kindergartens that help women's access to the labor market, and so on. Firms benefit from such flexibility and access to skills because these conditions are critical for competitive advantage in knowledge-intensive economies: "Firms do not develop competitive advantages in spite of systems of social law protection but because of it" [40].

\section{Regulatory Trade-offs}

The welfare goals and regulations of a state need, of course, to be paid for if they are to be realized; new law-making and economic potentials are instruments for reaching these goals. Analytically, a neo-liberal perspective may view the building of such potentials in modern states as basically directed by three goals: low inequality, low unemployment and low public expenses. These socio-economic goals are linked to three distinct policy choices that are characterized by a "trilemma". This trilemma occurs because it is difficult to pursue successfully all three goals simultaneously as long as there are trade-offs between them [44]. At this point, and before elaborating this statement further, there is a need to define and distinguish the notions of trilemma and trade-offs. For these purposes, I shall follow the work of Pollitt and Bouckaert [20]:

Regulatory trade-offs: where there is more than one 
desideratum or more than one problem to be alleviated, there will inevitably be the failure to attain other desiderata or the worsening of different problems. This is a situation, therefore, where decision-makers are obliged to balance between different things that they very much wish to achieve but cannot possibly have them all at the same time-indeed, having more of one desirable thing entails having less of another. In the political world, appropriate choices often are those that essentially make the best out these unavoidable, constrained conditions with the guidance good governance grounded on a pragmatic approach. Yet norms, values and traditions will affect these choices by making one set of options more preferable than the other. Governments thus tend to compromise the goal that is least ideologically important to them [45] in order to maximize the others in their struggle to retain their position of political superiority. We may take the following as an example. According to the perspective of historical institutionalism [46], if decision-makers were to engineer the use of social and economic potentials as short-term instrumental capital, then the long-term perspectives aiming for sustainability and the supremacy of good governance values will often be insufficiently communicated.

Torben Iversen [40] has highlighted this ideological aspect of the trilemma arising from the challenges of the global age of keeping unemployment, inequalities and public expenses in check, in short, the ideological aspect involved in social-capital tradeoffs. One strategy was to deregulate labor markets to reduce the power of employee unions and to increase wage flexibility. The governments of the Anglo-Saxon tradition, the US, the UK, New Zealand and Australia during the 1980s exemplified these neo-liberal policies. Another strategy was both to accept the consequences for employment resulting from a compressed wage structure and to seek to limit the disruptive effects by discouraging the entry of women into and by facilitating the exiting from the labor market, the latter being primarily affecting the elderly through early retirement. This is the typical pattern of choice we find in some Continental European countries.

The final option was to accept the slow growth of employment in private-service sectors but simultaneously to pursue an expansive employment strategy through expansion of public-sector services in order to balance the effective demand in the framework of Keynes. This strategy also strove to improve the educational resources for younger people as a policy approach towards building social capital. The social democratic governments in the Nordic countries, where the ideological tenor favored the financing of higher public expenses by full employment and by high tax rates, often chose this option.

As we observe in this process of compromising goals and policies, social law-making, regulatory models, administrative traditions and path-dependency play essential roles for what decision-makers consider to be designed appropriate choices and how they implement their strategic thinking on social capital [47]. We may argue that the trade-offs involved in European social-capital policy have this following inconsistency. On the one hand, creating jobs and employment in the private-service sector is a positive strategy in that it does not disturb the budgetary balance; however, this strategy has certain trade-offs: lower wages, higher non-wage costs and the inducing of negative inequality in the sense of lowering the degree of employment in the population and thereby reducing work productivity. On the other hand, the strategy of generating service jobs in the public sector also has trade-offs; the strategy indeed pushes the limits of already constrained and overloaded budgets [12].

Politicians in charge do have the obligation to make decisions. Concerning social and economic potentials, they look for a European model to minimize the trade-offs, that is, to find a model for flexible job creation, for social equality and for welfare, but all within a sustainable economy [24,48].

\section{European Welfare-State Law and Regulatory Trade-offs}

In our context, and with the structure of European Union law as the legal environment, we may briefly describe the trade-offs of equality-employment and public expenses of the European welfare-state models in the framework of innovative versus non-innovative regulatory choices with regard to law-making as the following [26]:

- The trade-offs in the liberal welfare-state regulatory model: As pointed out before, the Anglo-Saxon regulatory tradition weighs market solutions and regulatory measures and has the lessening of state intervention as an explicitly expressed objective for the service sector. Universal welfare and health coverage are not guaranteed. The employer provides the workers' health and social insurance, while the government covers the health expenses for the poor and the elderly who fall outside this insurance system.

- In this tradition, the response to the equality-employment tradeoffs was to give job creation and labor-market flexibility priority while it reduced job protection and social security. The use of contracting workers reduced the power of unions and increased wage inequality during the 1980s. The politicians and economists believed in a flexible labor market that would make full use of economic capacity and promote job creation, innovation and growth through a flexible labor 
market without fixed tariffs and expensive welfare services; the engineering of short-term social capital was part of this belief. For neo-liberal economists, market flexibility is the ultimate precondition and solution for increasing productivity and revitalizing the European economy in a globally competitive world.

- The trade-offs in the Corporatist welfare-state regulatory model: The Continental regulatory tradition depends on corporative solutions and state-interventionist measures. Health and social insurance are guaranteed, although the latter is a mixture of public and private institutional arrangements. Traditional welfare services are kept in the public domain as "services of general interest", that is, as a public responsibility. Trade unions are strong, but the problem is that there are too few jobs created. Reaching Hall's third-level institutional change does not, then, come through quickly enough.

- In this tradition, the response to the equality- employment trade-offs was to accept the employment consequences of a formal wage structure and hierarchical and rigid system of professionals, the latter of which also dominated the bargaining area. The labor market remained inflexible and the unemployment rate relatively high. Policies for the liberation of social and economic potentials did not stand up to solutions that obstinately remained "policies against the market".

- The trade-offs in the Universal welfare-state regulatory tradition: The Nordic regulatory tradition relies on laws and public institutional solutions with regard to social equality, interventionist measures, universal welfare services and public-health and social-insurance arrangements as the goals and means for the building of social capital. Institutional changes at Hall's three levels have created public innovations. Owing to the use of the mechanism of marketize in the public sector, like outsourcing and contracting out arrangements and the selective reorganization of public administration to Public-Law Agencies (PLAs) and Private-Law Bodies (PLBs), indirect governance by regulation has become common, and trade-union power has diminished since the 1980s [11,17,26].

- In this tradition, the response to the equalityemployment trade-offs was to accept sluggish employment growth in private services while expanding the public-service sector and public expenses, which resulted in high taxes. The influence of professionals in the main bargaining arena was limited because Nordic unions, unlike unions in countries such as Germany and France, were sharply divided between blue- and white-collar workers. In addition, the governments took anticipatory measures for building knowledge capital, such as life-long learning, adult education and continuous training in order to adjust skills to the changing needs in both the private and public sectors. Close to 20 percent of all adults (those between the ages of 25 and 65) participate in some kind of adult education every year, compared with an average of around eight percent for the EU as a whole. A rather flexible labor market has developed as a result of the implementation of this concept. The pay-off from the universal welfarestate facilitates the general acceptance of the relatively high tax level.

The Nordic countries have a long shared history and have experienced similar legal, social and economic developments. The most common feature of their systems is a well developed welfare-state characterized by its universalism, which means both that all citizens are entitled to basic social benefits and job protection and that there is high level of social spending, high taxes and a large public sector. They have succeeded in achieving a high degree of labor-market flexibility and are close to fulfilling one of the goals of the Lisbon Process of an overall employment rate of 70 percent.

Employment policies lie at the heart of the Nordic countries' labor-market regulatory policy, just as social-security policies lie at the heart of their welfare-state policy [49]. The framework of the two policies is innovation and long-term social-capital building, and the innovative achievement of flexicurity. Obviously, these policies pay off only when they are associated with low inequality and high public-welfare expenses and employment.

Even if they did not initiate and end the Lisbon Strategy, the Nordic EU member countries are very much comfortable with it-particularly its initial triple focus on the labor market, employment and social inclusion in a knowledge-based economy and under regulatory governance [43]. Actually, the similarity between the priorities of the Lisbon Process and the past and current actions of social-capital building in the Nordic countries have led some to ask whether or not the Lisbon reform agenda was simply an ambitious attempt by these countries to put their welfare-state policy in line "with the market," and the flexicurity model has been firmly imprinted onto Europe's economic and social regulatory model [24].

This interpretation is unlikely the case. The launching of the process of comprehensive renewal by the participants in Lisbon in 2000 represented a collective recognition of the challenges the EU faces and the need for a common response that would be able to draw on the best 
elements and paths of each member state's social and economic models and regulatory law traditions. The challenge was the regulatory trade-offs of the Union. The Nordic approach showed a possible regulatory welfare state path based on universal social arrangements secured by public law.

\section{REFERENCES}

[1] N. Veggeland, "Taming the Regulatory State: Politics and Ethics,” Edward Elgar, Cheltenham, 2009.

[2] N. Veggeland, "The New Regulatory State: Idea Discourses and Governance Conflicts,” Gyldendal Akademisk, Oslo, 2010.

[3] J. Tinbergen, “International Economic Integration,” Elsevier, Amsterdam, 1965.

[4] J. P. Olsen, "Maybe It Is Time to Rediscover Bureaucracy?” Journal of Public Administration Research and Theory, Vol. 16, No. 1, 2005, pp. 1-24. doi:10.1093/jopart/mui027

[5] M. Ferrera, "European Integration and National Social Sovereignty: Changing Boundaries, New Structuring," Paper, University of Padavia, Italy, 2002.

[6] P. Pierson, "Post-Industrial Pressures on the Mature Welfare States,” In: J. Pierre, Ed., Debating Governance: Authority, Steering, and Democracy, Oxford University Press, Oxford, 2001, pp. 80-106.

[7] B. Rosamond, “Theories of European Integration,” MacMillan Press, London, 2000.

[8] L. Jan-Erik, “New Public Management," Routledge, London, 2000.

[9] G. Majone, “The Rise of the Regulatory State in Europe,” West European Politics, Vol. 17, No. 3, 1994, pp. 77-101. doi:10.1080/01402389408425031

[10] N. Veggeland, "Europapolitikk, Innenrikspolitikk og Kommunene,” Kommuneforlaget, Oslo, 2005.

[11] N. Veggeland, "Post-National Governance and Transboundary Regionalization: Spatial Partnership Formations as Democratic Exit, Loyalty and Voice Options,” In: O. Kramsch and B. Hooper, Eds., Cross-Border Governance in the European Union, Routledge, London, 2004, pp. 157-170.

[12] Organization for Economic Cooperation and Development, "Modernising Government: The Way Forward," Organization for Economic Cooperation and Development Publishing, Paris, 2005.

[13] T. Iversen, “Capitalism, Democracy and Welfare,” Cambridge University Press, Cambridge, 2005.

[14] Organization for Economic Cooperation and Development, "Distributed Public Governance: Agencies, Authorities and Other Government Bodies,” Organization for Economic Cooperation and Development Publishing, Paris, 2002.

[15] A. S. Millward, "The European Rescue of the NationState,” Routledge, London, 2000.
[16] P. de Buck, "The Social Dialogue and the Role of Social Partners in the EEA,” EFTA Bulletin, 2004, pp. 73-78.

[17] D. W. Urwin, "The Community of Europe: A History of European Integration since 1945,” Longman, London, 1996.

[18] O. G. Austvik, "Internasjonal Handel og Økonomisk Integrasjon,” Gyldendal Akademisk, Oslo, 2002.

[19] H. Wallace and W. Wallace, "Policy-Making in the European Union,” Oxford University Press, Oxford, 2004.

[20] C. Pollitt and G. Bouckaert, "Public Management Reform: A Comparative Analysis,” Oxford University Press, Oxford, 2004.

[21] I. D. Koukiadis, "The Imminent Retirement of Socialism and the Hope of a New Social State,” Epitheorisi Ergasiakon Scheseon, Athens, 2006.

[22] J. Hayward and A. Menon, “Governing Europe,” Oxford University Press, Oxford, 2003. doi:10.1093/0199250154.001.0001

[23] J. K. Glenn, “EU Enlargement,” In: M. Cini, Ed., European Union Politics, Oxford University Press, Oxford, 2004, pp. 211-228.

[24] D. Janssen, "Retreat or Relaunch: Choices for the Lisbon Agenda,” Europe's World: The Only Europe-Wide Policy Journal, No. 1, 2005, pp. 54-57.

[25] EU Program 2006. http://www.euroactiv.com/

[26] N. Veggeland, "Paths of Public Innovation in the Global Age: Lessons from Scandinavia,” Edward Elgar, Cheltenham, 2007.

[27] European Policy Centre, “The Nordic Model: A Recipe for European Success?” European Policy Centre, Working Paper, Vol. 20, 2005.

[28] V. Timonen, "New Risks-Are They Still New for the Nordic Welfare States?” In: P. Taylor-Gooby, Ed., New Risks, New Welfare: The Transformation of the European Welfare State, Oxford University Press, Oxford, 2004, pp. 55-83.

[29] A. Mayhew, “Lisbon's Single Size Doesn't Fit All,” Europe's World, 2005.

[30] D. O’Sullivan, "Prize Pupil or Prodigy? The Nordic Model and the Lisbon Reform Agenda,” European Policy Centre, Working Paper, 2005, pp. 32-37.

[31] S. Kuhnle, "The Scandinavian Welfare State in the 1990s: Challenged but Viable,” In: M. Ferrera and M. Rhodes, Eds., Recasting European Welfare States, Frank Cass, London, 2000, pp. 209-228.

[32] P. Pierson, "Politics in Time: History, Institutions and Social Analysis,” Princeton University Press, Princeton, 2004.

[33] K. A. Røvik, “Translations and Trends: Ideas That Shape the 21 Century,” Fagbokforlaget, Bergen, 2007.

[34] C. Knill, "The Europeanization of the National Administrations,” Cambridge University Press, Cambridge, 2001. doi:10.1017/CBO9780511491986 
[35] G. Majone, "Regulating Europe,” Routledge, London, 1996. doi:10.4324/9780203439197

[36] G. Majone, "From the Positive to the Regulatory State: Causes and Consequences of Change in the Mode of Government,” Journal of Public Policy, Vol. 17, No. 3, 1997, pp. 139-189.

[37] U. Beck, "Risk Society: Towards a New Modernity," Sage Publication, London, 1992.

[38] P. Taylor-Gooby, "New Risks, New Welfare: The Transformation of European Welfare State,” Oxford University Press, Oxford, 2004.

[39] F. Scharpf, "Governing in Europe: Effective and Democratic?” Oxford University Press, Oxford, 1999.

[40] T. Iversen, “Capitalism: Democracy and Welfare,” Cambridge University Press, Cambridge, 2005.

[41] D. Beetham, L. Byrne, P. Ngan and S. Weir, "Democracy under Blair: A Democratic Audit of the United Kingdom,” Politico’s Publishing, London, 2002.

[42] J. P. Olsen, "Europeanization,” In: M. Cini, Ed., European Union Politics, Oxford University Press, Oxford,
2004, pp. 333-348.

[43] Europe's World, The Only Europe-Wide Policy Journal, Autumn 2005.

[44] A. Wren, "Distributional Tradeoffs and Partisan Politics in the Postindustrial Economy,” Dissertation, Department of Government, Harvard University, 2000.

[45] R. K. Weaver, “The Politics of Blame Avoidance,” Journal of Public Policy, Vol. 6, No. 4, 1986, pp. 371-398. doi:10.1017/S0143814X00004219

[46] M. Cini, "European Union Politics,” Oxford University Press, Oxford, 2004.

[47] U. Sverdrup, “Implementation,” In: P. Graziano and M. P. Vink, Eds., Europeanization: New Research Agendas, MacMillan, Palgrave, 2007.

[48] P. N. Rasmussen, "What Lisbon Has Lacked Is Political Courage,” Europe's World, Autumn 2005, pp. 60-70.

[49] T. Iversen and A. Wren, "Equality, Employment, and Budgetary Restraint: The Trilemma of the Service Economy,” World Politics, Vol. 50, No. 4, 1998, pp. 507-546. 